\title{
LANGUAGE IDEOLOGY IN CROSS-CULTURAL COMMUNICATION
}

\author{
Author: Amelia Yanka and Ed Rex
}

\begin{abstract}
According to Franz Boas, the socio-cultural context within which a speech community thrives and upon which its collective preferences and linguistic prejudices are established should be considered only as a "secondary rationalization" and should be relegated below the more important aspect of studying the inherent dynamics of the language itself. In the process, Boas developed an alternative linguistic model where race, language, and culture may be separated from-and can function independently of-each other. This model allows an external observer to develop a keen understanding of any given language without the need to solicit value-laden information-such as cultural, religious, or social judgments-from native speakers. Thus, secondary rationalizations, while important, may be bypassed in any attempt of a non-native linguist to understand and reconstruct a given language.
\end{abstract}

Keyword: Language, Multilingual, Ideology, Cross-cultural, Communication.

Amelia Yanka, Ed Rex. Language Ideology in Cross-Cultural Communication. International Journal of Science and Research (IJSR), 2020, International Journal of Science and Research (IJSR), 4 (2), pp.22-31.

\section{Introduction}

The findings of Paul Kroskrity's decades-long work on the Arizona Tewa people greatly challenge this linguistic theory. Kroskrity implicitly demonstrated that compared with Boas' model, the concept of linguistic ideologies is the more accurate framework by which language may be methodically grasped.

The Arizona Tewa people belong to the Tewa Pueblo group that now lives in northeastern Arizona following revolts against the Spanish in 1680 and 1696 that led to mass migrations and the Arizona Tewa's eventual co-existence with their Hopi hosts. Their centuries- 
old association with and long exposure to the Hopi people and other speech communitiesEnglish, Spanish, Navajo-resulted to their adoption of some basic elements of Hopi society as well turning many Arizona Tewa into multilingual speakers.

However, what Krosktrity highlighted in his work is the remarkable linguistic purism that characterizes the Arizona Tewa language. Unlike those in similar socio-cultural contacts between or among speech communities, the close and prolonged language contact of the Arizona Tewa with the Hopi people resulted only in very minimal linguistic influence. In fact, of all the peoples who migrated following the late 17 th century revolts, only the Arizona Tewa group retained its

language even to the present. In particular, the group's language contact with the Hopi people that covered around 200 years of socio-linguistic exchange resulted only in extremely low vocabulary borrowings (i.e., loan words) from the Hopi language.

Language contact may be defined as a linguistic engagement between two or more human groups with different languages (in this sense, the Arizona Tewa and the Hopi). The potential outcomes of language contact include stable bilingualism or multilinguism, language shifts, pidgin languages and language death. In the context of the Arizona Tewa, language contact with highly similar and disparate cultures resulted to the multilingualism of many Arizona Tewas but peculiarly left the Arizona Tewa language "pure" even after centuries of close language contacts-100 years with the Apaches, 150 years with the Spanish, and 191 years with the Hopi.

Kroskrity partly attributes this resistance to linguistic borrowings to the linguistic conservatism of the Arizona Tewas, hailing this group of people as "paragon of linguistic conservatism." The Tewa saying "My language is my life" affirms the Tewas' collective awareness of the fundamental significance of their language to the group's very existence/soul.

However, Kroskrity goes further by introducing the concept of linguistic ideology as an alternative socio-cultural interpretation of the Tewas' resistance in assimilating foreign influences into their language. Using linguistic ideology that is rooted in a local context, Kroskrity identifies "kiva speech" as the driving force that kept the Arizona Tewa language remarkably intact for many generations. That is, everyday Tewa speech and linguistic discourses "display a common pattern of influence" from kiva speech-a form of linguistic discourse performed in religious subterranean chambers as sacred altars are erected. In a practical and all-pervading sense, kiva

23 | Amelia Yanka, Ed Rex. Language Ideology in Cross-Cultural Communication. International Journal of Science and Research (IJSR), 2020, International Journal of Science and Research (IJSR), 4 (2), pp.22-31. 
speech became the paramount model used by the Arizona Tewa even in their everyday language. Kroskrity cites four cultural preferences exhibited in kiva speech that primarily established the resistance of the Tewa language to foreign influences. These are 1) regulation by convention [which is exemplified by the use of prayers and song texts]; 2) indigenous pluralism [characterized by strong prohibition against foreign words]; 3) strict compartmentalization [maintenance of linguistic and discourse types]; and, 4) linguistic indexing of identity [application of language as an indicator of the speaker's identity]. 


\section{Discussion}

The world is truly an amazing place. Throughout my travels I have had the privilege of meeting some incredible people. Learning and embracing their culture has been a humbling experience.

Today's business environment is rapidly expanding to various geographical locations. New technology and the internet have opened up new opportunities on a global level. This is fantastic! We can promote our business anywhere in the world and as a result working with people remotely has never been easier. Cross cultural communication has become the new norm. However somewhere along the line we have dismissed its importance, taken it for granted and overlooked the importance of communicating with different cultures.

Hint; If you do not communicate appropriately and do not observe cultural differences you may encounter obstacles, or worse; not even get your foot in the door!

To reach a broad audience, English being the universal language is used. When communicating with people from different backgrounds in English it is natural to assume that they speak and think the same language - right? Well this is not always the case. Many cultures have certain etiquette when communicating. It is recommended you do some research on the culture before embarking on your endeavours.

\section{A. Communication Involves Building Strong Relationships}

When dealing with people from other cultures, we need to communicate in a way that minimises misunderstandings and strengthens professional relationships. Many companies that conduct their business overseas offer training in cross cultural communication. When working with other people, or travelling overseas for work or pleasure, it pays to do a some research at the beginning. This can reduce misunderstandings and confusion later on.

Here are some tips for cross cultural communication;

1. Opening and Closing Conversations There may be customs behind who, when and how to address people, this includes who speaks first and the correct way to end the conversation. And as much as it may horrify some westerners - this also includes gender

25 | Amelia Yanka, Ed Rex. Language Ideology in Cross-Cultural Communication. International Journal of Science and Research (IJSR), 2020, International Journal of Science and Research (IJSR), 4 (2), pp.22-31. 
differences.

2. Presumptions When communicating in English we tend to overlook any differences. We reach a comfortable rapport and may get carried away with our cultural behaviour. It is easy to fall into this trap because we are speaking the same language - this also includes body language. And remember Don't judge people by their accents or their language fluency instead adapt your style to the demands of the situation

3. Keep it Simple When you communicate keep in mind that English may be their second language. It is a mistake to assume that every businessperson speaks and understands good English. Avoid slang, phrases and the use of fillers such as "like", "you know... " ah... " If you are not being understood do not repeat your words instead try other words, use stories and examples to illustrate the point you are trying to make. And whatever you do - Do not shout or speak loudly when you are trying to get a point across - they are not deaf.

4. Pronunciation Take the time to learn to pronounce names correctly. The most important word in any language is a person's name. Make the effort of learning to pronounce names correctly. The individual will feel respected and valued.

5. Appropriate Topics of Conversation In some cultures topics involving money or family may be disrespectful. Research the customs surrounding commercial transactions so you are better prepared.

6. Humour Western cultures occasionally try to build rapport with humour and in some cases this may not be appropriate. Your humour may not be understood or accepted. This is another area where misunderstandings can occur.

\section{B. Cross-Cultural Presentations in Languages}

The international flavour of many people's jobs naturally means that there is greater interaction between people from different cultures. Within the business environment, understanding and coping with intercultural differences between people is critical to ensuring that interpersonal communication is successful.

Intercultural awareness is necessary for two reasons. Firstly, it minimises the possibility

26 | Amelia Yanka, Ed Rex. Language Ideology in Cross-Cultural Communication. International Journal of Science and Research (IJSR), 2020, International Journal of Science and Research (IJSR), 4 (2), pp.22-31. 
of misunderstandings and/or the causing of offense through intercultural mishaps. Secondly, it is a means to maximising the potential of business relationships through the utilization of intercultural differences productively.

One area within the business environment in which intercultural awareness is a necessity is in the business presentation. Directors, managers, salespeople, consultants and business personnel are regularly required to deliver presentations. However, when one is asked to give a presentation to an audience from a different culture there are intercultural factors that can hinder the success of a presentation.

By way of illustrating some of the intercultural differences in presentations, these tips to effective cross cultural presentations are offered:

\section{- Language:}

The language you use in a cross cultural presentation is important. Although the majority of the language that is used in a cross cultural presentation will be understood by an English speaking foreign audience, a speaker must be careful when it comes to slang, idioms or phrases.

If an Englishman were to talk of being "knocked for six" or "bowled over" he may very well be met with puzzled expressions. More subtly, when an American talks of a 'billion' he means a thousand million, whereas in the UK this would mean a million million. Try and keep language simple.

\section{- Body Language:}

Pay attention to your body language in a cross cultural presentation. Some cultures are quite animated and will appreciate hand gestures and the expression of emotion through the body. Others expect speakers to remain calm and would find such behaviour over the top. Similarly pay attention to the use of gestures. The thumbs up may mean 'good' in the USA but it means something very different in Iran. Eye contact can also be a major intercultural difference. Some cultures consider strong eye contact a sign of sincerity, others find it overbearing and an invasion of privacy. Do your cross cultural homework before a presentation.

\section{- Time:}

Be aware of different approaches to time across cultures. Some cultures prefer a structured, timetabled approach to conducting business affairs, others are more casual. In countries where a start time is considered a guide rather than a definite, allow time for 
networking or engage in some chit chat until others arrive. Oppositely, if you arrive late to a meeting in a punctual culture, expect some negative feedback. Always show the appropriate stiffness or flexibility depending on the culture.

\section{- Emotions:}

Some cross cultural presentations may be in front of a small number of people and deal

with sensitive issues in a pressured environment. In such intercultural situations one should always keep their emotions in check. In some cultures a certain amount of cross examination or scrutiny may occur. If this happens bear in mind the positive intentions behind such actions, i.e. the questions are only being posed to establish facts, not to undermine you. Never lose patience, show frustration or display anger. To do so will lead to a loss of credibility.

\section{- Style of Presentation:}

Different cultures learn and take in information in varying ways. One should always try and tailor their presentation style to meet the needs of the target culture. Some cultures, such as Europeans, prefer information to be presented in detail and in a way that sets down foundations that act as the support to a final argument or point. In such a presentation the speaker should gradually lead the audience, using a logical succession of points, to a conclusion. On the other hand, some cultures, like the US, prefer a much faster paced presentation that is bottom-line orientated, meaning the presenter speaks from a point rather towards a point.

\section{- Use of Technology:}

Power Point is not the default method of giving a presentation across the world. Some countries many not even have the technical capabilities to accommodate this so one would need to adapt to the resources at hand, whether it be an Over Head Projector or blackboard. Some cultures do not even like a visual element to presentations and find much more worth in words and personality.

\section{- Content:}

In a cross cultural presentation, ensure you tailor the content of a presentation to the audience. Different cultures expect different things from a business presentation. Long term orientated cultures may be excited about future projections and figures, but others would rather learn more about the presenter's credentials, accomplishments and experience. A presenter needs to ask whether the target culture will appreciate factual, statistical information presented visually, 
or a more personal oratory approach.

\section{- Audience Participation:}

Audiences react in different ways across cultures. Some are very engaging and are willing to participate in exercises and Q\&A sessions, others are the opposite. Audiences also show respect in many ways. A Japanese audience may close their eyes while listening; a US one may clap when a good point is made and a Saudi one may do nothing at all.

\section{Conclusion}

Finally, cultures are always changing; even amongst themselves. I found that the younger generation will try to communicate differently in order to move forward in the modern world. One thing to bear in mind is that no matter how "modern" they may appear on the surface, their core values and customs may still be strong in their psyche. This may sound confusing however it is important to understand that they too are trying to bridge the gaps between cross cultural communication and surviving in the business world.

Although the number of areas where one could point to intercultural differences in presentations is vast, for the sake of brevity the above mentioned areas have been highlighted as a way of drawing attention to some of the major ones. It is hoped these can then act as a foundation to improving ones insight into the way intercultural differences manifest in the business environment.

To conclude, linguistic ideologies provided the most useful model in terms of generating a deep understanding of the Arizona Tewa language. In contrast to the precepts developed by Franz Boas, Kroskrity maintains that any reconstruction of language that will not consider the naturalized, dominant ideologies of a speech community will be an incomplete framework at best.

\section{References}

Aldyan, R. A., Warto, W., \& Marimin, M. (2019). " Ngalab Berkah" on the Tradition to Open Luwur the Sunan Kudus Tomb. International Journal of Multicultural and Multireligious Understanding, 6(4), 156-165. 
Boas, F. (1989). A Franz Boas reader: the shaping of American anthropology, 1883-1911. University of Chicago Press.

Cameron, D., Frazer, E., Harvey, P., Rampton, M. B. H., \& Richardson, K. (2018). Researching language: Issues of power and method. Routledge.

Cutler, J. (2018). The Cross-Cultural Communication Trainer's Manual: Volume Two: Activities for Cross-Cultural Training. Routledge.

De Marco, A. (2019). Teaching the Prosody of Emotive Communication in a Second Language. In Second Language Acquisition-Pedagogies, Practices and Perspectives. IntechOpen.

Dewi, E. W., Drajati, N. A., \& Yunus, M. M. (2019). Exploring Intonations in Sesame Street's Puppet Shows: A Phonological Perspective. Issues in Language Studies, 8(2), 32-47.

Dogancay-Aktuna, S., \& Hardman, J. (2018). Teaching of English as an international language in various contexts: Nothing is as practical as good theory. RELC Journal, 49(1), 74-87.

Habibi, H. (2016). PERAN KI DALANG BASARI (1950-2003) DALAM PERKEMBANGAN ISLAM DI GEGESIK CIREBON. Jurnal Tamaddun: Jurnal Sejarah dan Kebudayaan Islam, 1(2).

Habibi, H. (2018). Protecting National Identity Based On The Value Of Nation Local Wisdom. International Journal of Malay-Nusantara Studies, 1(2), 24-40.

Keith, K. D. (Ed.). (2019). Cross-cultural psychology: Contemporary themes and perspectives. John Wiley \& Sons.

Kroskrity, P. V. (1992). Arizona tewa ktva speech as a manifestation of linguistic ideology. Pragmatics.

Quarterly Publication of the International Pragmatics Association (IPrA), 2(3), 297-309.

Kroskrity, P. V. (1993). Language, history, and identity: Ethnolinguistic studies of the Arizona Tewa. University of Arizona Press.

Kroskrity, P. V. (2000). Regimenting languages: Language ideological perspectives. Regimes of language: Ideologies, polities, and identities, 1, 34.

Lifintsev, D., \& Wellbrock, W. (2019). Cross-cultural communication in the digital age. Estudos em Comunicação, 1(28).

Payne, G., Ordeix, E., \& Rom, J. (2018). New Perspectives on Cross-Cultural Communication and Corporate Diplomacy. Trípodos, (42), 9-10.

Poór, J., Kollár, C., Szira, Z., Taras, V., \& Varga, E. (2018). Central and Eastern European Experience of the X-Culture Project in Teaching International Management and CrossCultural Communication. Journal of Intercultural Management, 10(1), 5-41.

Rex, E. (2019, December 24). Understand Cross-Cultural Analysis. https://doi.org/10.31219/osf.io/wtg3x

Rohman, T. N., Nababan, M., \& Santosa, R. (2019). An Analysis of Translation in Translated Drama Script Entitled Waiting for Godot. International Journal of Multicultural and Multireligious Understanding, 6(6), 195-200.

Rtischeva, O. V. (2019). Content of language cultural universal in cross-cultural communication.

30 | Amelia Yanka, Ed Rex. Language Ideology in Cross-Cultural Communication. International Journal of Science and Research (IJSR), 2020, International Journal of Science and Research (IJSR), 4 (2), pp.22-31. 
Журнал Сибирского федерального университета. Гуманитарные науки, 12(1).

Rubtcova, M., \& Pavenkov, O. (2019, September). Teaching Tolerance As the Basis of Effective Cross- Cultural Communication. In ISETE-International Conference on Innovative Research Practices in Economics, Business and Social Sciences (ICIRPEBS). Kanyakumari, Tamil Nadu, India.

Wang, J. (2018). Analysis of New Concept English from the Perspective of Cross-cultural Communication-A Case Study in Book 2. Theory and Practice in Language Studies, $8(10), 1270-1277$.

Zhang, W. (2019, October). Study on Cultural Identity and Cross-cultural Communication in Teaching of International Students in China under the Context of the Belt and Road. In 2019 International Conference on Advanced Education Research and Modern Teaching (AERMT 2019). Atlantis Press.

31 Amelia Yanka, Ed Rex. Language Ideology in Cross-Cultural Communication. International Journal of Science and Research (IJSR), 2020, International Journal of Science and Research (IJSR), 4 (2), pp.22-31. 